УДК 355.43:94(100)"'17"

ВОЙТОВИЧ Л.В.

https://orcid.org/0000-0002-9191-6537

https://doi.org/10.33577/2313-5603.34.2020.129-148

\title{
ПРОБЛЕМИ УЧАСТІ УКРАЇНСЬКОГО КОЗАЦТВА У ТРИДЩЯТИЛІТНІЙ ВІЙНІ
}

У дослідженні розібрано дискусійні проблеми участі українського козацтва у Тридцятилітній війні 1618-1648 рр. і пов'язані з ними стереотипи. Ці стереотипи залишаються спадщиною польської і української патріотичних історіографій, які намагалися приписати «своїм» участь у спільних або ж і чужих формуваннях. Звернена увага на особливості наборів підготованих контигентів найманих військ з Речі Посполитої католицькою коаліцією та Францією та особовий склад формувань польських козаків, так званих «лісовчиків». Встановлено, що формування «лісовчиків» були легкою кавалерією, ефективною при виконанні розвідувальних і сторожових завдань, рейдах по території, зайнятій противником та переслідуванні відступаючого противника. Формування українського козацтва були піхотними, а піхоти у війську Речі Посполитої постійно не вистарчало. Тому дозволити найняти іншу піхоту, окрім українських козаків, Річ Посполита просто не могла. Під час війн поляки самі наймали угорську, німецьку чи чеську піхоту. Проаналізовані битви під Гуменним (1619), на Білій горі (1620), кампанії в Сілезії, на Рейні, в Гессені та Люксембурзі та балтійську експедицію. Обгрунтована гіпотеза щодо тотожності полковника Тараського 3 гетьманом Федоровичем Тарасом (Трясилом). Детально розглянено проблему участі і ролі козаків у здобугті Дюнкерка (1646) та участі у цих подіях Богдана Хмельницького, Івана Сірка та Солтенка.

Ключові слова: Тридцятилітня війна, українське козацтво, лісовчики, битва під Гуменним, битва на Білій горі, битва при Івоа, Дюнкерк.

Тридцятилітня війна (1618-1648) була першою загальноєвропейською війною, у якій взяли участь більше сотні великих i малих держав. Міжконфесійне протистояння католиків з протестантами привело до утворення у Священній Римській імперії Протестанської Євангелістської унії (1608), яку очолив курфюрст Пфальца Фрідріх V фон Віттельсбах (16.08.1596-19.11.1632), та Священної Католицької ліги (1609), очоленої герцогом Баварії і курфюрстом Максиміліаном I фон Віттельсбахом (27.04.157327.09.1651), втягнуло не тільки сусідні протестантські Нідерланди, Данію та Швецію, але й католицьку Францію, яка виступила на

Войтович Леонтій Вікторович, доктор історичних наук, професор, завідувач кафедри історії середніх віків i візантиністики Львівського національного університету ім. Івана Франка, м. Львів.

(С Войтович Л. В., 2020 
боці протестантів, налякана обіймами австрійських і іспанських Габсбургів, які ще у 1609 р. укласти між собою союзну угоду, спрямовану проти неї. Річ Посполита була готова підтримати Католицький табір, але амбітний авантюрист король Сигізмунд III, який сам загубив достатньо реальну можливість утвердження на московському престолі королевича Владислава Вази, визнаного московським боярством, рішився на чергову інтервенцію та поход на Москву у 1617-1618 рр., який скінчився Деулінським перемир'ям та підготовкою до продовження війни. Такі ж стосунки були у польського короля і з Швецією. 3 обома сусідами Річ Посполита була змушена воювати і під час Тридцятилітньої війни (Östergren, 2005; Leitsch, 2009; Cac, 2010; Wimmer, 2013). Тому безпосередня участь Польщі у цій війні обмежувалася ії бойовими діями проти шведів у рамках польсько-шведської війни, яка була продовженням попередньої політики Сигізмунда III як шведського короля, усуненого шведами. Поряд 3 тим Польща не заперечувала проти участі своїх підданих у складі найманих контигентів, спочатку на боці Католицької ліги, а потім і Франції.

Тридцятилітня війна була періодом розквіту професійних найманих армій. Підготовка бійців була дорогою і довгою. Наприклад, аркебузирів чи мушкетерів, у яких ефективною була тільки залпова стрільба, готували роками. Тому наймали на службу цілі роти і полки підготованих бійців, які прибували зі своєю зброєю і своїми офіцерами та були готовими до використання на полях битв (Войтович, 2016: 5-11).

У польській та литовській частинах Речі Посполитої були обмежені можливості для вербування найманців-професіоналів. 3 можливого контигенту потрібно виключити затяжні шляхетські хорогви, 3 набором та утриманням яких мали проблеми i самі гетьмани, а також надвірні хорогви князів та окремих магнатів, які утримували їх своїм коштом. Переважно це була панцерна кавалерія, з якої виділялися гусари, які у польському війську, на відміну від інших, були важкою кавалерією. Особливо не вистачало піхоти. У 1563 р. було створено т. зв. кварцярне військо, яке утримувалося від чверті (кварти) доходів 3 королівщин (територій, які платили податки безпосередньо в коронний скарб). Це військо налічувало всього 3 тис. кінноти і 1 тис. піхоти (Nowak, Wimmer, 1981: 292). Кварцярна піхота мала роти по 200 чол., які ділилися на почети по 20 чол., очолені войсковими товаришами, 
щеренговці яких звалися пахолками або драбами. У 1578 р. за короля Стефана Баторія була створена вибранецька піхота, яка комплектувалася і утримувалася за принципом 1 піхотинець від 20 ланів королівської землі (Horski, 1893: 24). Вибранці були мушкетерами, які проходили щорічний 3-місячний вишкіл. Десятники були озброєні алебардами. Вибранецькі роти у 1580 р. включали трьох офіцерів (ротмістра, поручника і хорунжого), барабанщика, 26 десятників-алебардистів і 236 мушкетерів. Але їх було небагато, всього близько 3 тис. в короні і близько1 тис. у великому князівстві. Під Псков у 1581 р. прибуло 12 рот вибранців чисельністю 1878 чол. (Wimmer, 1978: 140-141, 152-153). Тому нестачу піхоти закривали найманцями. У польському війську були наймані угорські гайдуцькі роти чисельністю по 100 чол. та німецькі роти жолдаків, чисельністю 400 чол., серед яких, крім мушкетерів, були і пікінери (Крип'якевич, 1936: 144). Піші регіменти налічували різне число рот. Перший такий регімент був сформований у 1576 р. і налічував 600 жовнірів (Войтович, Овсінський, 2017: 766). На теренах Речі Посполитої були тільки дві війської формації, де можна було набрати кваліфікованих професіоналів: українські козаки і польські козаки, звані лісовчиками. 3 українського козацтва можна було набрати досвідчених піхотинців-мушкетерів (Войтович, 2012: 64-79), 3 польських козаків - легку кінноту. Лісовчики були організовані і озброєні за козацькими зразками i прославилися сміливими діями на комунікаціях противника та рейдами по глибоких тилах. Ця формація була організована полковником Олександром Юзефом Лісовським (1580-11.10.1616), активним учасником шляхетського Рокошу Зебжидовського (1607), скараним на вигнання (баніцію), який з 6 тис. поляків і 8 тис. запорожців приєднався до московського самозванця Лжедмитрія II. У 1609 р. його полк прославився здобуттям Суздалі, Шуї, Ярославля і Кінешми. У 1610 р. лісовчики перейшли на королівську службу і здійснили успішний рейд до Торопця і Пскова. У 1615 р. Лісовський з 2 тис. лісовчиків здійснив ще сміливіший рейд, здобувши Карачев, Орел, Болхов, Белев і Перемишль. Раптово помер, впавши з коня під Вязьмою. Лісовчики обходилися без артилерії та обозів, утримуючись за рахунок реквізій та грабунків. Соратники Лісовського зберегли цю формацію і були готові служити за добру плату (Dzieduszycki, 1844: t. 1-2; Ekes, Kotarski, Lisowski, 1972: 471-473; Wisner; Зорин, 2009; Зорин, 2012: 1-203; Зорин, 2017). 
У Західній Європі добре знали про українське козацтво, особливо після того, як цісарю Рудольфу II вдалося залучити козаків до війни проти турків наприкінці XVI - початку XVII ст. (Січинський, 1991: 51-65; Наливайко, 1992: 81-99). Польське козацтво стало більш відомим після участі лісовчиків у Тридцятилітній війні. Загалом козаками називали переважно запорозьких козаків, тобто українських козаків. Також в цілому у Західній Європі всіх вихідців із земель Речі Посполитої називали поляками. Всі ці речі потрібно враховувати при дослідженнях військових контигентів із Речі Посполитої на полях битв Тридцятилітньої війни, при цьому розуміючи, що кінні підрозділи могли бути набрані як з лісовчиків, так і з запорожців, а піші - виключно із запорожців (Наливайко, 1998: 223). Не можна погодитися 3 висновками, наприклад, Володимира Голобуцького, який вважав, що до найманого польського контигенту, який воював у Франції, входила німецька піхота (Голобуцьький, 1994: 317). Наймані війська коштували завжди дорого i їх складно було набрати, а тим більше під час такої війни. I хто став би набирати в польських землях німецьких піхотинців або хто б дозволив забирати вже залучених до польського війська?

Недалекоглядна політика польського уряду у козацькому питанні штовхала козацьку верхівку на найману військову службу до іноземних володарів. Якщо сусідня Московська держава брала козаків, одразу ж розформовуючи їх частини і розсилаючи по дальніх гарнізонах, включаючи північні Холмогори (Документи російських архівів з історії Украӥни., 1998: 196-218, 320-322), то у Західній Європі іноземні наймані контигенти були звичним явищем. Їх наймали на певні періоди цілими частинами зі своїми старшинами за визначену плату, після чого вони поверталися додому. Уряд Речі Посполитої не заперечував проти наймання козаків, сподіваючись, що у такий спосіб їх проблеми самі по собі будуть вирішені. Те ж саме стосувалося лісовчиків, яких прагнули позбутися ще швидше, як тільки-но відпала небхідність у цій формації, розуміючи, що по потребі вони повернуться і знайдуть можливість для поповнення своїх рядів. Зрозуміло також, що наймали не реєстрових козаків, яких утримував уряд, а козаків нереєстрових, яких завжди було в рази більше і з якими уряд мав проблеми, небажаючи визнавати реального стану речей. Козацькі гетьмани, яких уряд називав старшими (Брехуненко, 2011: 119-129), 
записували частину нереєстрових джурами або і ділили отриману плату, але це відбувалося у періоди воєн, а між війнами серед запорожців було достатньо досвідчених воїнів, яких можна було набрати на службу.

Література, присвячена проблемі участі українських козаків у Тридцятилітній війні, досить численна (Костомаров, 2004: 160-161; Dembolęcki, 1830: 74-75; Diwald, 1987: 123; Борщак, 1922; Борщак, 1924: 87; Gayecky, Baran,1969; Gayecky, Baran,1983; Баран, 1974: 76-81; Крип'якевич, 1914: 65-114; Костомаров, 2004: 48; Голобуичкий,1962: 84; Голобуцьький, 1985: 132-140; Голобуцький, 1994: 297-314; Wójcik, 1973: 580-585; Вергун, 1980: 626; Сергійчук, 1988: 68-71; Сергійчук, 1991: 129-134; Федорук, 1999: 87-98; Федорук, 2000: 116-120; Федорук, 2006: 450-453; Федорук, 2012: 258-261; Макух), але більшість дослідників не беруть до уваги зазначених особливостей набору і формування цих військ або по різному трактують інформацію джерел, що призвело до гострих дискусій і протилежних висновків з багатьох питань.

Спробуємо проаналізувати найважливіші дискусійні моменти цієї безперечно актуальної проблеми. Війна почалася доволі несподівано і застала обидві конфліктуючі сторони ще недостатньо підготованими. 5 травня 1618 р. протестантські депутати чеського сейму звернулися до імператора Священної Римської імперії Матвія фон Габсбурга 3 протестом на дії чеського короля Фердінанда Штірійського . У відповідь імператор оголосив їх бунтівниками. 23 травня 1618 р. королівські намісники Славата i Мартінец та секретар уряду Фабріцій були викинуті 3 вікна Чеської канцелярії у Празі .

Ці події призвели до початку бойових дій, які розпочалися у червні 1618 р. із здобуття чеським військом, очоленим генераллейтенантом графом Індржіхом Матяшем фон Турн-Вольсасін (24.02.1657-26.01.1640) (Hallwich, 1895: 70-92), замку Крумлов на р. Влтаві, який розмірами та потужністю поступався тільки Празькому Граду. 21 листопада 1618 р. кондотьер на чеській службі граф Ернст фон Мансфельд (1580-29.11.1626) (Krüssmann, 2010) 3 20-тис. найманим різноетнічним протестантським військом після трьох штурмів здобув Пльзень. Іспанські Габсбурги перекинули армію 3 Фландрії, яка одночасно 3 австрійським військом вторглася у Чехію. Граф Турн з полковником Андреасом Шликом блокували фландрську армію у Будвайзе. Австрійські емісари 
(посол граф Адольф Алтген і Петер Фукс (Баран, 1970: 76) за мовчазної згоди короля Сигізмунда III почали вербувати козаків на австрійську службу.

Але події розвивалися дуже стрімко. У травні 1619 р. граф Турн виступив на Відень, на 3'єднання 3 ним йшло угорське військо трансильванського князя Габора Бетлена (1580-15.01.1629) (Wittmann, 1952; Wittmann, 1856: 35-57). 10 червня 1619 р. при Заблаті під Чеськими Будейовіцами граф Мансфельд був розбитий імперським генерал-полковником-лейтенантом Карлом Бонавентурою де Бюкуа (9.01.1571-10.07.1621) (Weyhe-Eimke Arnold von; Koblasa). Хоча це змусило графа Турна повертати у Чехію, чеський сейм оголосив недійсним обрання чеським королем Фердінанда II Габсбурга. Його підтримали сейми Моравії, Сілезії i Лужиць. 26 серпня 1619 р. чеським королем обрали Фрідріха V курфюрста Пфальц, не стільки як главу Протестантської унії, але як зятя анлійського короля, на допомогу якого чехи розраховували. Курфюрст прийняв це обрання і 4 листопада 1619 р. був коронований.

Тим часом, розгромивши біля Требішова на початку вересня 1619 р. лідера угорських католиків графа Дьєрдя Другета-Гомонаї ((1583-1620), який залишив Кашшу (Кошіце) і відступив через карпатські перевали до Галичини, 20-тис. угорське військо князя Габора Бетлена 16 жовтня 1619 р. здобуло Пожонь (Братиславу), а у листопаді підійшло до Відня. 27 листопада 1619 р. Габор Бетлен здобув літню резиденцію імператорів Еберсдорф.

Між тим барон Дьєрдь Другет-Гомонаї не гаяв часу. Він ще раніше провадив переговори з командиром лісовчиків полковником Валенти Рогавським, який погоджувався на кондотьєрську службу за умови оплати по 15 злотих за 5 тис. козаків і пахолків та повного права на військову здобич. Зрештою, отримавши частину виплат, Рогавський виступив до Спіша наприкінці жовтня з 4 тис. лісовчиків, але був розбитий і відступив до Кросна. Тут Рогавський разом 3 австрійськими емісарами долучили ще щонайменше 6 тис. запорожців. Рогавський став гетьманом всього війська. Як пізніше заявив Габору Бетлену крайчий великий коронний, а згодом один 3 героїв Хотинської битви 1621 р., Станіслав Любомирський (1583-17.06.1649) у цьому війську «польської крові було мало» (Szabó, 1881). Сучасник цих подій пізніший львівський бургомістр, хроніст і поет Бартоломей Зіморович (20.08.1597-14.10.1677), у 
збірці поезій, присвячених лісовчикам, виданій у Кракові у 1620 р., писав, що лісовчики розмовляли українською мовою (Wójcik, 1973).

Капітан Верхньої Угорщини Дьєрдь I Ракоці (8.06.159311.10.1648), якому Габор Бетлен доручив охорону свого тилу, довідавшись про приготування графа Другета, негайно повідомив свого князя. Але Бетлен не повірив, що Другет-Гомонаї зміг за такий короткий час зібрати значні сили. Його безпечність приспала пильність молодого Ракоці, який дозволив Другету з козаками форсувати Лубківський перевал. 21-22 листопада 1619 р. біля с. Стрипсько під Гуменним козаки і лісовчики розгромили 7-тис. військо Ракоці (2500 гусарів, 2 тис. комітатського ополчення та 2,5 тис. угорських опришків сободів), який втратив до двох тисяч і відступив до Шарошпотока, а потім замкнувся у потужному замку Макк, який козаки обложили (Nagy, 1969: 182-199; Papp, 2011: 915-973; Borbély, 2014: 295-309; Borbély, 2015: 110-208). У цій битві відзначилися ротмістри лісовчиків Єронім Кличковський та Станіслав Русиновський, які зі своїми хорогвами атакували противника, а потім імітували втечу, заманивши угорців в оточення. Було здобуто 17 прапорів, три 3 яких Рогавський відіслав до короля Сигізмунда III, а решту - імператору. Козаки підійшли до Кашші (Кошіце) та Еперешу (Пряшева), але прихильники Габсбургів переважно були репресовані і Другета ніхто не підтримав (Kudelka, 1902: 187-199; Баран, 1970: 76-81).

Коштів на подальше утримання майже 10-тис. війська у графа Другета не було. Військо збунтувалося. Белзький хорунжий Адам Ліпський, який представляв особу короля, наполягав на поході під Відень проти Габора Бетлена. Другет хотів продовжувати боротьбу з Ракоці. Більшість козаків разом з Рогавським через Дукельський перевал вернули за Карпати 16 грудня 1619 р., попутно грабуючи села і містечка. У Дуклі на військовій раді було скинено з гетьманства Рогавського і замінено на Ліпського.

27 листопада 1619 р., отримавши у щойно здобутому Еберсдорфі звістку про розгром війська Ракоці, князь Бетлен Габор зняв табір і повернув назад. У січні 1620 р. він уклав перемир'я з Габсбургами. Залишившись без козаків, граф Дьєрдь Другет-Гомонаї не зміг протистояти Габору Бетлену і невдовзі загинув 21 липня 1620 р. (Dzieduszycki, 1844: 200-202; Szilágyi, 1893: 70-71; Angyal, 1898: 240-241; Teodorczyk, 1988-1989: 324-325). 
Габор Бетлен підступив до карпатських перевалів і польний гетьман коронний Станіслав Конєцпольський з великим конюшим коронним князем Криштофом Збаразьким спішно перекидували військо до перевалів, щоб стримати угорців від вторгнення. В таборі Ліпського у Жмігроді було обрано новим очільником гетьманом Єроніма Кличковського, який 34 тис. лісовчиків та запорожців вступив на цісарську службу. Решта війська 3 Рогавським, які не захотіли найматися, було розпущено (Dzieduszycki, 1844: 196-201).

Серед розпущеного війська було багато саме лісовчиків, бо полковнику Рогавському вдалося невдовзі зібрати 1200 бійців, 3 якими він взяв участь у виправі коронного гетьмана до Цецори. Він зумів вирватися з близько 700 бійцями, і далі він успішно воював 3 татарами у війську Станіслава Конєцпольського аж до смерті 30 листопада 1625 р., очолюючи рештки лісовчиків (Dembolęcki, 1830: 33-36; Magnuszewski, 1978).

Єронім Кличковський з своїми козаками воював у Чехії i загинув в околицях Горна 4 березня 1620 р. (Dzieduszycki, 1844: 340-341; Kersten, 1967: 557-558). Формацію очолив полковник Станіслав Русиновський. У іï складі залишалося щонайменше 3 тис. лісовчиків і українських козаків. Папський нунцій у Венеції в реляції до Риму від 20 серпня 1620 р. повідомляв про прибуття до цісарського війська 5 тис. козаків «з-над Чорного моря», яких очолював капітан Хасана Тараса (Gayecky, Baran, 1969: 75). Тому не можна відкидати можливої участі українців у знаменитій битві на Білій горі 8 листопада 1620 р.

Імперське військо К. Б. де Бюкуа з'єдналося з військами глави Католицької ліги баварського герцога Максиміліана I та його фельдмаршала Йогана Церкласа фон Тіллі (1559-30.04.1632) (Klopp; Wittich, 1894: 314-350; Rill; Kaiser; Rebitsch), досягнувши чисельності 28 тис. Тіллі відтіснив військо Фрідріха V до Праги. Вирішальна битва відбулася 8 листопада 1620 р. біля Білої Гори. Протестантським військом чисельністю близько 23 тис. при 10 гарматах командував герцог Христіан I фон Ангальт-Бернбург (11.05.1568-17.04.1630). Обидві армії складалися 3 найманців. Герцог Християн I не зумів використати переваги місцевості, розгорнувши військо рівномірно по фронту. Він пробував застосувати нідерландську побудову, але його військо було непривчене до цієї системи. П'ять терцій Тіллі і п'ять баварських терцій 
Максиміліана виявилися сильнішими. Хаотичний відступ протестанського війська прикрив герцог Вільгельм фон Саксен-Веймар (27.07.1598-17.05.1662), який до останнього залишався на полі бою. 7-тис. військо трансильванського князя Габора Бетлена не встигло підійти на поле битви. Протестанти втратили 5 тис. проти 2 тис. у католиків. У складі кінноти Тіллі (7550 осіб) був полк козаків Станіслава Русиновського, які розгромили 5-тис. угорську кінноту, що складала третю лінію протестантського війська, і здобули 52 штандарти, в т. ч. і головне знамено чеського короля Фрідріха V та його шатро (Kavka, 2003; Krüssmann, 2010).

Після цієї битви Станіслав Русиновський з частиною козаків вернувся до Польщі, взяв участь у битві під Хотином (1621), де був важко поранений, після чого через певний час знову опинився на цісарській службі (Starowolski: 1978: 272). Але в армії Тіллі залишився польсько-український полк полковника Станіслава Стройновського, який у 1622 р. налічував у своїх рядах від 3800 до 5 тис. осіб (Theatrum Europaeum oder Warhafftige beschreibung alter..., 1662: 545). Зрозуміло, що переважна більшість козаків, які поповнили його ряди після Хотинської війни, були запорожцями, бо за межами реєстру залишалося більше 30 тис. осіб, які мали досвід участі у цій війні, тоді як лісочиків залишилося буквально кілька сотень, зібраних пізніше Русиновським після того, як на сеймі 1624 р. було підтримано ухвалу сеймику у Вишні (1622) і всіх лісовчиків на інфамію (позбавлення честі) i баніцію (вигнання). Полк С. Стройновського відзначився у Сілезії в битвах під Клодзьком (травень 1622) та під Габельшвертом (червень 1622), а також під Спішом у Словаччині (серпень 1622 р.) (Dzieduszycki, 1844: 107-109, 143-156, 207-212). Далі цей полк було перекинено на Рейн, де він прославився знаменитою переправою під Друсенгеймом (1622) і воював до 1625 p. (Teodorczyk, 1972: 180). Після 1624 р. до цієї частини долучилися рештки лісовчиків, звинувачених у рокоші 1622 р. збунтованого війська, з яким не розрахувалися за Хотинську війну (до якого вони не мали відношення) і засуджених сеймом на вигнання. Командував цією формацією у 1625-1626 рр. полковник Ідзі Калиновський, який почав кар'єру ще за Олександра Лісовського у 1610 р. під час московської авантюри. Воювали ці козаки навіть на Італійському фронті (Dzieduszycki, 1844: t. 1: 212, 249, 332, 360; t. 2: 30, 52, 116, 273-274, 283, 345, 389, 443-444; Koblasa, 2002: 454-455). 
Рештки лісовчиків були виведені до Польщі і у 1626-1628 pp. Воювали у Прусії в ході польсько-шведської війни 1626-1629 pp. під командуванням полковника Миколая Мочарського. У невдалій битві під Гнєвом (22.09-1.10.1626) (Podhorodecki, 1975: 154-160; Skworoda, 2006) їх було близько 400 осіб у складі двох хорогв, а у переможній битві під Чорним (Гаммерштейном) (12-17.04.1627) теж кілька сот осіб (Podhorodecki, 1975: 166-172). Сам Мочарський залишався на королівській службі і загинув у битві з українськими 16 грудня 1637 р.

Після поразки під Брейтенфельдом (17.09.1631) та смертельного поранення Тіллі на р. Лех (15.04.1632), немаючи чим стримати наступ протестантів, на боці яких виступала блискуча шведська армія Густава II Адольфа, імператор знову звернувся до відставленого генералісимуса Альбрехта Венцеля Еусебіуса фон Валленштейна герцога фон Фрідланд (24.09.1583-25.02.1634), який прибув 3 армією, набраною власним коштом (Wittich, 1900: 582-641; Boehn, 1926; Diwald, 1987; Weir, 1993; Ивонин, 2003: 48-77; Mann, 2006; Rebitsch, 2010; Schuberth \& Reichel, 2012). Знаменитий полководець намагався найняти якомога більше козаків, але наштовхнувся на протидію польського уряду в умовах конфронтації з Москвою і Швецією при постійних можливостях серйозних кримських нападів. Крім того, у 1626 р. під командуванням барона Ді Дона в армії Валленштейна вже служило 4 тис. козаків, які були відпущені без оплати за останні три місяці, що теж впливало на вербування нових контигентів, яке 8 грудня 1631 p. оголосив генералісимус, обіцяючи щоденне утримання в розмірі 2 фунтів хліба, 1 фунта м'яса, 2 пива, 1 вино, півкорця вівса на тиждень для коня і плату в розмірі 6 рейнських талярів на місяць. Тому у 1632 р. у війську Валленштейна в Сілезії воювало тільки 2 тис. українських козаків. 29 січня 1633 р. під Штреленом козаки були розгромлені шведами і втратили більше 500 осіб. Далі, незважаючи на заборону короля Владислава IV найму і виведення війська з Речі Посполитої, число козаків у лютому 1633 р. сягнуло 6 тис. Але сюди ввійшли і рештки цих підрозділів, які воювали у Ломбардії, біля озера Комо і на Рейні. Вони вже не складали єдиної формації, а були розкидані по різних полках армії Валленштайна (Баран, 1978: 40-51).

Восени 1631 р. через Москву до запорозьких козаків була відправлена шведська місія у складі капітана П'єра д’Адміраль і 
фендріх Жак де Грев. Залишивши в Києві свого провідника путивльця Григорія Гладкого, місія заблукала і замість Запорожжя потрапила до Переяслава, де реєстровий гетьман Іван КулагаПетражицький заарештував іiі, повідомив польський уряд і таємно передав йому шведських післанців (Szelagowski, 1899: 685-700; Грушевський, 1922: 129-132).

Чергову польсько-шведську війну 1635 р. теж можна вважати однією 3 кампаній Тридцятилітньої війни. Польща поспішала скористатися ситуацією після загибелі шведського короля Густава II Адольфа. Але шведський флот повністю контролював балтійське побережжя. Польський флот у складі десяти фрегатів i двох галер одразу ж був розгромлений. Тоді Владислав IV наказав козацькому полковнику Костянтину Вовку, учаснику Хотинської битви і ротмістру коронного війська у Смоленській кампанії 1632-1634 рр., набрати півтори тисячі січовиків, добре обізнаних 3 морською справою, і прибути до Ковна (Каунаса). Одночасно у литовському Юрбурзі під наглядом козацького майстра почалося будівництво 30 чайок, необхідне обладнання для яких доставляли коштом уряду. 19 липня 1635 р. 3 гирла Німану флотилія чайок під командуванням полковника Вовка вирушила до Кенісбергу. Але до того часу бойові дії у Прибалтиці стихли і почалися переговори, в ході яких шведи захопили флагманський фрегат польського флоту «Чорний орел». I король наказав атакувати шведську ескадру, яка стояла у Піллау. Вовк провів свої чайки вночі з 30 на 31 серпня і несподівано атакував шведів, захопивши в абордажному бою великий шведський транспорт, який пізніше був обміняний на польський флагманський фрегат. Після цього бою козацькі чайки ще два тижні крейсерували між Піллау і Кенігсбергом. 12 вересня 1635 р. було укладено мир на 26 років. 23 вересня 1635 р. король наказав розрахуватися 3 козаками, виплативши їм у Торуні 15 тис. золотих і дозволивши їм забрати здобуті трофеї. Чайки 3 бойовими припасами мали бути відведені до Ковна і там зберігатися до нових потреб (Мамчак, 2005: 111-114).

Тоді ж за угодою від 23 вересня 1635 р. полковник Павло Носковський привів в імперську армію козацький контигент за плату по 6 талерів рядовим козакам. Сам полковник мав отримувати 200 талерів. Козаки воювали у Пікардії та Ельзасі, але восени 1636 р. залишили службу через вічні проблеми з оплатою за службу (Войтович, Голубко, 2018: 143-144). 
Польський уряд не розплатився з козаками, які брали участь у Смоленській кампанії і не дуже противився набору козаків до імперської армії, яка вела переможну кампанію на Рейні. Козаки брали участь у Гессенській кампанії 1636 р., зокрема у здобуті Сеста (27 вересня 1636 р.) та інших міст (Баран, 1974: 20-21). 4 тис. козаків, очолених полковником Тараським, воювало в складі імперського війська у Люксембурзі проти французької армії принца Луї де Бурбон-Суассон (1.05.1604-6.07.1641) (Courcelles Jean-Baptiste-Pierre Jullien de, 1821: 43-46). Вони відзначилися перемогою при Івоа (Федорук, 2006: 460-463).

Виникає питання, хто такий полковник Тараський? Чи не був це Федорович Тарас на прізвисько Трясило (+ 1639), гетьман нереєстрових козаків $(1630,1634-1635)$, чигиринський реєстровий полковник (1632) (Ковалецьь, 2016: 33-45), учасник Смоленської кампаніі, який розбив московське військо під Щелкановим (10 квітня 1634 р.) (Gayecky, Baran, 1969: 140). На січневій раді 1635 р. він не тільки здав гетьманство, але й спалив власний двір і покинув козацькі землі (Зорин, 2017: 64). Вважають, що колишній гетьман відразу ж кинувся шукати притулку на Дону та московській службі, але Тарас Чорний, який зустрічається в документах цього періоду, скоріше родич гетьмана Григорія Чорного ніж Тарас Федорович. Схоже, все ж таки, що Тарас Федорович 3 своїми прихильниками подався на цісарську службу і відзначився у боях в Люксембурзі.

Найбільш дискусійним залишається питання участі українських козаків у здобутті Дюнкерка у 1646 р. (Федорук, 1999: 87-98). Вступ Франції у Тридцятилітню війну на боці протестатського союзу змусив останню воювати на кількох фронтах із значними втратами. Ще керівник французького уряду кардинал герцог Арман-Жан дю Плессі де Рішельє (9.08.1585-4.12.1642) через свого посла 3 березня 1637 р. звернувся до польського уряду 3 проханням про залучення на французьку службу козацьких контигентів (Pamiętniki Albrychta Stanisława X. Radziwiłła kanclerza w. Litewskiego, 1839: 337). Польща дотепер дозволяла наймати війська тільки цісарю і католицькій коаліції. Тому переговори йшли важко. Наступник Рішельє кардинал Джуліо Мазаріні (14.07.1602-9.03.1661) продовжив ці переговори. Французи допомогли полякам розв'язати суперечку 3 Вюртенбергом у 
справі контрибуції з сілезьких князівств Ополє і Ратибор, які були під польським протекторатом, а взамін поляки таки дозволили набрати їм козацький контигент у 1645 р.

21 вересня 1644 р. віконт де Брежі, французький післанець при польському дворі, доносив кардиналу Мазаріні про налагодження контактів 3 козаками, зазначивши при цьому, що до переговорів залучений «... і нині дуже здібний полководець Хмельницький, його тут при дворі поважають». У жовтні 1644 р. де Брежі писав: «...цими днями був у Варшаві один $з$ старшин козацької нації полковник Хмельницький, про якого я мав честь писати Вашій еміненції. Він був у мене, я мав з ним дві розмови. Це людина освідчена, розумна, сильна в латинській мові, що стосується служби козаківу його величності, то якщо війни 3 турками не буде, Хмельницький готовий допомогти мені в цій справі» (Половцчов, 1902: 123). Зрозуміло, що мова не йшла про наймання реєстрових козаків, просто із запорожцями контакт можна було встановити тільки через реєстрову старшину. У переговорах брали участь також Солтенко та полковник коронного війська Пржемський. Вони погоджувалися набрати 1800 піхотинців та 800 кавалеристів 3 оплатою по 12 ріксталерів, а старшині по 120 (Борщак, 1922). В ході цих переговорів Богдан Хмельницький навіть їздив до Франції і особисто зустрічався з генералісимусом принцом Луї II де Бурбон-Конде (8.09.1621-11.12.1686). Це підтвердив П'єр Шевальє, французький офіцер і секретар графа де Брежі, який брав участь у цих перемовинах і супроводжував козаків до Дюнкерка, у своїй книзі, виданій у Парижі у 1663 р. «Хмельницькому, який з'явився з глибин Росії у Францію порадили, щоб показати себе тут, звернутись до Вас, монсиньйор, який і може засвідчити його доблесть» (Chevalier, 1663: 12; Шевальє, 1993: 19). Сам Б. Хмельницький у 1655 р. при зустрічі з французьким агентом 3 гордістю називав принца Конде «своїм старим вождем» і з задоволенням згадував дні, які провів у Франції (Половцов, 1902: 123; Крип'якевич, 1990: 48). Останнє було би можливим тільки, як би Хмельницький справді зустрічався 3 принцом Конде, що, у свою чергу, було можливим тільки у Франції.

Набраний контигент близько 2-2,5 тис. піхотинців було зібрано у Гданську, куди 24 квітня 1654 р. прибув граф де Брежі, щоб особисто перевірити зосередження і відправку цього війська, а далі з П'єром Шевальє і полковником Пржемським ці козаки 
були перевезені морем до Копенгагена і далі до Кале, де вони поступили під командування генерал-майора Клода де Летуфа барона де Сipo (12.07.1600-6.04.1652). Барон почав свою кар'єру у 15 років як волонтер голландської армії, у якій пробув до 1620 р. Далі він служив у війську герцога Савойї у Генуї, воював проти князя Габора Бетлена Габора (1625р.), потім у війську герцога Франца Альберта фон Саксен-Лауенбург, воював у католицькому війську проти Данії (1627) та шведського короля Густава Адольфа (1635), повернувся до Франції, відзначився в Арpaci (1640) та в битві при Рокруа (1643). Після Дюнкерка став генерал-лейтенантом. Помер від мушкетної рани. Мемуари його були видані у Парижі у 1683 р. (Mémoires et la vie messire Claude de Létouf..., 1693). 3 легкої руки Ілька Борщака барон Сіро став полковником Іваном Сірком (Борщзак, 1922), що і призвело до стереотипу, який гуляє досі.

Облога Дюнкерка тривала 37 вересня по 11 жовтня 1610 p. Цю важливу фортецю, яку з моря підтримувала іспанська ескадра, обороняв 5-тис. гарнізон під командуванням досвідченого генерала маркіза Лейдена. Іспанці не вірили в можливість облоги і штурму такої потужної фортеці. Але, здобувши Фюрн, принц Конде перекрив канали, якими 3 Дюнкерка можна було дістатися до бельгійських міст. Крім того, 10 лінійних кораблів і 15 фрегатів союзного голландського флоту заваджали іспанській ескадрі. У розпоряджденні принца Конде було 10 тис. піхоти на 5 тис. кавалерії. Військо відразу ж приступило до будівництва циркумвалаційної лінії для захисту від можливого наступу імперського фельдмаршала Пікколоміні $з$ метою деблокади фортеці. Маршали Жан де Гассіон (20.08.1609-2.10.1647) та Йосшфс Ранцау (18.10.1609-14.09.1650) зайняли флангові позиції, які уприралися у берегову лінію, а сам Конде - центр. Козацький регімент під командуванням барона Сіро був у складі корпусу маршала Гассіона. Складність підвозу продовольства і важкі кліматичні умови не дозволяли розтягувати облогу надовго. В апрошах розмістили 60 гармат і перший приступ відбувся 24-25 вересня, який маркіз Лейден відбив із значними втратами. 1-2 жовтня французи повторили приступ. Гарнізон його відбив, хоча втратив один з бастіонів, у штурмі якого брали участь козаки. У маркіза Лейдена була надія на підмогу з моря, але іспанці не наважилися атакувати голландську ескадру i повернули назад. Гарнізон пробував вирватися через французькі позиції поруч з пляжем, але 
був відкинений. В цій контратаці теж брали участь козаки. Після цього гарнізон капітулював на почесних умовах 11 жовтня 1646 р. i козаки вступили в місто як окрема частина під своїми прапорами (Histoire du Siége de Dunkerque par M. le Prince..., 1649; Coste, 1748: 86-95; D’Aumale Henri d'Orléans duc, 1889: t. 5, p. 93; t. 7, p. 169).

Далі частина козаків, невдоволена затримкою оплати, перейшла на службу до іспанців. Решта була перекинена у Лотарингію, звідки вони повернулися додому (Половцов, 1902: 123-124; Борщак, 1922; Крип'якевич, 1990: 48-49).

Під Дюнкерком не було Богдана Хмельницького та Івана Сірка, а також, напевно, і Солтенка, але це зовсім не значить, що там були виключно польські найманці, бо французькі автори військовики і дипломати називали їх поляками (Wójcik, 1973: 575-585; Анциишкін, 2005: 120-122; Голобуцьький, 1985: 132-140), адже досі в Європі всіх вихідців 3 колишнього Радянського Союзу називають росіянами. Найняти підготованих польських піхотинців у 1645 р. не було фізичної можливості, бо, крім кварцярної та ланової піхоти, решту польської піхоти складали угорські та німецькі найманці. Жодну з цих формацій поляки б не дозволили забрати, тим більше, враховуючи військові плани короля Владислава IV. Лісовчиків у цей час теж не залишилося, зрештою вони теж не мали піхоти. I для чого для набору польської піхоти потрібно було залучати козацьких старшин Хмельницького та Солтенка? I для чого граф де Брежі замовляв для Мазаріні «книжки, написані руською мовою»? (Вергун, 1980: 625). Ця проблема, як і багато інших проблем, пов'язаних з участю українських козаків у Тридцятилітній війні, потребує подальших глибоких досліджень.

\section{Використані посилання:}

Анцишкін I. (2005). До питання про «французький похід» Івана Сірка. Козаџька спадщина. Вип. 2. С. 120-122.

Баран О. (1970). Козаки на Закарпатті в 1619-ім році. Украӥнський історик. № 1-2 (37-38). C. 76-81.

Баран О. (1974). Козаки на імператорській службі в роки 1635-1636. Український історик. Ч. 1-3 (41-43). С. 5-22.

Баран О. (1978). Валленштайн і козаки. Український історик. Ч. 1-3 (57-59). C. $40-51$.

Борщак I. (1922). Козаки Хмельницького під Дюнкерком 1645 (за невиданими документами архівів військового міністерства і міністерства закордонних справ у Парижі). Українська трибуна. Варшава. 6 січня. 
Борщак I. (1924). Гетьман Пилип Орлик і Франція. Сторінки дипльоматичної історії. Записки НТШ. Львів. Т. 134-135. С. 79-136.

Брехуненко В. (2011). Гетьман чи старший? За лаштунками номенклатури козацьких провідників (XVI - перша половина XVII ст.). Україна: культурна спадщчина, начіональна свідомість, державність. Bun. 20. Actis testantibus. Ювілейний збірник на пошану Леонтія Войтовича. Львів. С. 119-129.

Вергун I. (1980). Чи козаки Хмельницького брали Дюнкерку в 1646 році? Визвольний илях. Кн. 5 (386).С. 625-626.

Войтович Л. (2012). Козацька піхота: озброєння, організація, бойові можливості на тлі європейської лінійної піхоти кінця XV - середини XVII ст. Проблеми історії країн Центральної та Східної Європи. Збірник наукових праць. Кам'янецьПодільський. Вип. 3. С. 64-79.

Войтович Л. (2016). Професійні наймані армії: результат «порохової революції» чи еволюції військової справи? Воєнно-історичний вісник. № 3 (21). С. 5-11.

Войтович Л., Овсінський Ю. (2017). Завершення переходу до професійних найманих військ. Історія війн і військового мистецтва. Харків. Т. 1. С. 739-817.

Войтович Л., Голубко В. (2018). Козацьке військо на іноземній службі у 1618-1648 рр. Історія війн і військового мистецтвв. Харків. Т. 2. С. 143-144.

Голобуцкий В. (1962). Дипломатическая история Освободительной войны украинского народа 1648-1654 г2. Киев. 360 с.

Голобуцький В. (1985). Про одну легенду з історії України XVII ст. Украӥнський історичний журнал. № 9. С. 132-140.

Голобуцький В. (1994). Запорозьке козацтвво. Київ. 537 с.

Грушевський М. (1922). Історія України-Руси. Київ-Львів. Т.8. 856 с.

Документи російських архівів з історї Украӥни. (1998). Т. 1. Документи до історії запорозького козацтва 1613-1620 pp. Упорядники Л. Войтович, Л. Заборовський, Я. Ісаєвич, Ф. Сисин, А. Турилов, Б. Флоря. Львів. 442 с.

Зорин А. (2009). Великий рейд Александра Лисовского (март-декабрь 1615 г.). Русский сборник. Брянск. Вып. 5. С. 224-232.

Зорин А. (2012). Александр Юзеф Лисовский: герой Смутного времени История военного дела: исследования и источники. Москва. Т. 3. С. 1-203.

Зорин А. (2017). Лисовчики: Александр Юзеф Лисовский и его полк в истории Смутного времени. Москва. 232 с.

Іванцов I. (2002). Повстання украӥнського народу проти иляхетської Польщчі 1635-1638 рр. Київ. 289 с.

Ивонин Ю. (2003). Альбрехт Валленштейн. Вопросы истории. Москва. № 1. C. $48-77$.

Ковалець Т. (2016). Тарас Федорович: спроба реконструкції історичногог образу, або козацька доля - наче голлівудський сценарій. Військово-науковий вісник. Київ. Вип. 25. С. 33-45.

Костомаров М. (2004). Богдан Хмельницький. Київ. 843 с.

Крип'якевич I. (1914). Козаччина у політичних комбінаціях 1620-1630-х років. Записки НТШ. Львів. Т. 117-118. С. 65-114.

Крип'якевич I. (1936). Запорозьке військо. Історія украӥнського війська. Львів: видання Івана Тиктора. Ч. 2. 169 с.

Крип'якевич I. (1990). Богдан Хмельницький. Львів. 408 с.

Макух С. (2004). Казаки наемники в Тридцятилетней войне 1618-1648. Зеркало недели. № 16 (491). 24-29.04.2004. 
Мамчак М. (2005). Костянтин Вовк, полковник. Мамчак Мирослав. Флотоводиі Украӥни. Історичні нариси, хронологія походів. Снятин. С. 111-113.

Наливайко Д. (1992). Козацька християнська республіка. Київ. 495 с.

Наливайко Д. (1998). Очима Заходу: Рецепџія Украӥни в Західній Європі XI-XVIII cm. Київ. 578 с.

Половцов А. (1899). О малороссийских казаках на французской службе в 1646 г. Киевская Старина. № 5. С. 74-75.

Половцов А. (1902). О малороссийских казаках на французской службе в 1646 г. Труды ХІ Археологического съезда. Киев. Т.2. С. 123.

Сас П. (2010). Запорожиі у польсько-московській війні наприкіниі Смути 1617-1618 рр. Біла Церква. 512 с.

Сергійчук В. (1988). Українські козаки у Франції. Наука і суспільство. № 3. С. 68-71.

Сергійчук В. (1991). Іменем війська запорозького. Украӥнське козаџтво у міжнародних відносинах XVI- середини XVII cm. Київ. 153 с.

Січинський В. (1991). Чужинці про Украӥну. Київ. 256 с.

Федорук А. (1999). До проблеми участі козаків у боях за Дюнкерк 1646 р. Питання стародавньої та середньовічної історії, археологї й етнології: Збірник наукових статей. Чернівці: Золоті литаври. Т. 3. С. 87-98.

Федорук А. (2000). Козаки в контексті військового мистецтва Тридцятирічної війни (1618 - 1648 рр.) Середньовічна Свропа: погляд з кіния XX cm. Чернівці: Золоті литаври. С. 116-120.

Федорук А. (2006). Бій під Івоа 1636 р.: особливості тактичного мистецтва козаків у Тридцятирічній війні. II Міжнародний науковий конгрес українських істориків «Украйнська історична наука на сучасному етапі розвитку». Кам'янець-Подільський, 17-18.09.2003. Доповіді та повідомлення. Кам'янецьПодільський; Київ; Нью-Йорк; Острог: Вид-во На УОА, 2006. Т. 2. С. 460-463.

Федорук А. (2012). «Лисовчики» в битве на Белой горе 1620 г. (К вопросу о военной деятельности украинского казачества после окончания русской Смуты). Смутное время в России: конфликт и диалог культур. Санкт-Петербург, 12-14 октября 2012 г. Санкт-Петербург. С. 258-261.

Шевальє П. (1993). Історія війни козаків проти Польщзі з розвідкою про їхнє походження, краӥну, звичаї, спосіб правління та релігію і другою розвідкою про перекопських татар. Київ. 219 с.

Angyal D. (1898). Magyarország története II. Mátyástól III. Ferdinánd haláláig. Magyar Nemzet története. 6 köt. Ed. S. Szilágyi. Budapest. 320. 1.

D'Aumale Henri d'Orléans duc. Histoire des princes de Condé pendant les XVI et XVII siécle. T. 5. Paris, 1889. - 584 p.; T. 7. Paris, 1896. 653 p.

Biernacki Witold. (2006). Biala Góra 1620. Gdańsk. 376 s.

Boehn Karl von.(1926). Wallenstein. Wien. 185 s.

Borbély Zoltán. (2014). A Homonnai Druget György vezette Bethlen-ellenes mozgalom nemzetkóri hátteréhez. Bethlen Erdélye, Erdély Bethlene: A Bethlen Gábor tronra lépésének 400. évforduliján rendezett konferencia tanulmányai. Koloszvár. 295-309 old.

Borbély Zoltán. (2015). A Homonnai Drugethek Felsö-Magyarországon a 17. század elsö évtizedeiben. Eger. 2551.

Chevalier Pierre. (1663). Histoire de la guerre des Cosaques contre la Pologne. Avec un Discours de levr Origine, Pays, Moeurs, Gowernement et Religion. Et un autre des Tartares Précopites. Paris. 219 p. 
Coste Pierre. (1748). Histoire de Louis de Bourbon, second du nom, Prince de Conde rt premier price du Sang. Contenant ce qui s'eft paffé in Europe depuis 1640, jufques en 1686 inclufivement. A La Haye. 628 p.

Courcelles Jean-Baptiste-Pierre Jullien de. (1821). Dictionare historique et biographique des généraux français, depuis be onzième siècle jusqu'en 1821. Paris. $496 \mathrm{p}$.

Dembolęcki Wojciech. (1830). Przewagi elearów polskich co ich niegdy lisowczykami zwano, które czynili w państwach Cesarskich przeciwko heretykom... Dzieło wydane... Puławy. 254 s.

Diwald Helmut. (1987). Wallenstein. Biographie. Berlin. 575 s.

Dzieduszycki Maurycy. (1844). Krótki rys dziejów i spraw Lisowczyków. T. 1-2. Lwów. $560 \mathrm{~s}$.

Ekes Janusz, Kotarski Henryk, Aleksander Józef Lisowski (1972). Polski Słownik Biograficzny. Warszawa. T. 17. S. 471-473.

Gayecky George, Baran Alexander.(1969). The cossaks in the Thirty yars war. Roma. Vol. 1: 1619-1624. 140 p.

Gayecky George, Baran Alexander. (1983). The cossaks in the Thirty yars war. Roma. Vol. 2: 1625-1648. 240 p.

Godley Eveline. (1915). The Great Conde. A life of Louis II, De Bourbon, Prince of Condé. London. 638 p.

Hallwich Hermann. (1895). Turn-Valsassina, Matthias Graf von. Allgemeine Deutsche Biographie. Leipzig. Bd. 39. S. 70-92.

Histoire du Siége de Dunkerque par M. le Prince (Louis de Bourbon). Par Jean François Sarasin. (1649). Paris. 248 p.

Horski Konstanty.(1893). Historia piechoty polskiej. Kraków. 273 s.

Kaiser Michael. (1999). Politik und kriegführung. Maximilian von Bayern, Tilly und die katholische Liga im Dreisigjährigen krieg. Münster. 559 s.

Kavka Frantisek. (2003). Bilá hora a české dejiny. Praha. 325 s.

Kersten Adam. (1967). Hieronim Kleczkowski vel. Jarosz nazw. Takży Wojciechem, rzadziej Stanisławem (zm. 1620). Polski Słownik Biograficzny. Wrocław, T. 12/4. S. 557-558.

Klopp Onno. (1861). Tilly in dreisigjährigen kriege. Stuttgart. Bd. 1-2.

Koblasa Pavel. (2002). Buquoyové. Stručne dějiny rodu. Česke Budějovice. 79 s.

Kotarski Henryk. (1964 - 1965). Kalinowski Idzi. Polski Słownik Biograficzny. Wrocław. T. 11. S. 454-455.

Krüssmann Walter. (2010). Ernst von Mansfeld (1580-1626), Grafensohn, Söldnerführer, kriegsunternehmer gegen Habsburg im Dreisigjährrigen krieg. Berlin. $742 \mathrm{~s}$.

Kudelka Frank. (1902). Bitwa pod Humiennem. Przegląd Powszechny. T. 85. S. 187-199.

Leitsch Walter. (2009). Das Leben am Hof König Sigismunds III. von Polen. Wien: Verlag der Österreichischen Akademie der wissemschaffen. Bd. 1-4.

Magnuszewski Władysław. (1978). Zdziejów elearów polskich. Warszawa. 215 s.

Mann Golo. (2006). Wallenstein. Spiegel.Verlag. 1293 s.

Martin Juan Giménez. (1999). Tercios de Flandes. Madrid. 284 p.

Mémoires et la vie messire Claude de Létouf, chevalier baron de Sirot, lieutenant général des camps et armées du roy... sous les régnes des rois Henri IV, Louis XIII etc. Louis XIV. (1693). Paris. Vol. 1-2. 
Nagy László. (1969). Bethlen Gábor a független Magyarországért. Budapest. 484 p.

Nowak Tadeusz, Wimmer Jan. (1981). Historia oręża polskiego. 963-1795. Warszawa. $699 \mathrm{~s}$.

Östergren Stefan. (2005). Sigismund: en biografi över den svensk-polske monarken. Ängelholm: Fredestad. 340 s.

Pamiętniki Albrychta Stanisława X. Radziwiłta kanclerza w. Litewskiego. (1839). Poznań. T. 1. 431 s.

Papp Sándor. (2011). Bethlen Gábor, a Magyar királyság és a Porta (1619-1621). Századok. - Budapest. Nr 135 (2011-4). 915-973. 1.

Podhorodecki Leszek. (1985). Rapier i koncerz. Warszawa. 493 s.

Quatrefages René. (1983). Los tercios. Madrid. 522 p.

Quatrefages René. (1996). La revolucion militar moderna. El crisol español. Madrid. 438 p.

Rebitsch Robert. (2010). Wallenstein. Biografie eines Machtmenschen. Wien. 232 s.

Rill Bernd. (1984). Tilly. Feldherr für kaiser und Reich. Müncheen. 335 s.

Saller Rudolf. (2007). Reichsgraf Johann T'Serclaes von Tilly Chronik über Leben und Laufbahn. Altötting. $292 \mathrm{~s}$.

Schuberth Inger, Reichel Maik. (2012). Die blut'ge Affair' bei Lützen. Wallensteins Wende. Wettin. $304 \mathrm{~s}$.

Skworoda Paweł. (2006). Hammerstein 1627. Warszawa. 256 s.

Szabó Károly. (1881). Bethlen Gábor fejedelem politikai levelezése. Történelmi Tár. 2. füz. 283-343. 1.

Szelągowski A. (1899). Układy królewicza Władysława i dysydentów z Gustawem Adolfem w r. 1632. Kwartalnik Historyczny. Lwów. T. 13. S. 685-700.

Szilágyi Sándor. (1893). Rákóczy György. Budapest. 452. 1.

Szymona Starowolskiego Wojownicy sarmaccy. Przełożyl, wstępem poprzedzit $i$ przypisami opatrzyt Jerzy Starnawski.(1978). Warszawa. 294 s.

Teodorczyk Jerzy. (1972). Wojskowość polska w pierwszej połowie XVII w. Historia wojskowości polskiej. Wybrane zagadnienia. Warszawa. S. 177-193.

Teodorczyk Jerzy. (1988-1989). Walenty Rogawski. 2 pol. XVI w. - 1625.11.30. Polski Słownik Biograficzny. Wrocław. T. 31. S. 324-325.

Theatrum Europaeum oder Warhafftige beschreibung alter und jeden denckurirdiger Geschichten 1617-1629. (1662). Frankfurt am Mayn. T.1. 745 s.

Weir William. (1993). Fatal Victories. Connecticut. 272 p.

Weyhe-Eimke Arnold von. (1876). Karl Bonaventura Graf von Buquoy. Wien. 91 s. Wimmer Jan. (1978). Historia piechoty polskiej. Do roku 1864. Warszawa. 615 s.

Wimmer Jan. (2013). Polska-Szwecja. Konflikty zbrojne w XVI-XVIII wieku. Warszawa: NapoleonV. $253 \mathrm{~s}$.

Wisner Henryk. (1976). Lisowczycy. Warszawa. 356 s.

Wisner Henryk. (2013). Liszowczycy: Łupieżcy Europy. Warszawa. 200 s.

Wittich Karl. (1894). Tilly Johann T'Serclaes Graf von. Allgemeine Deutsche Biographie. Leipzig. Bd. 38. S. 314-350.

Wittich Karl. (1900). Wallenstein Albrecht Wenzel Eusebius von. Allgemeine Deutsche Biographie. Leipzig. Bd. 45. S. 582-641.

Wittmann Tibor. (1952). Bethlen Gábor mint hadszervezö. Budapest. 39.1

Wittmann Tibor. (1856). Bethlen Gábor és az 1628-1629 evi erdélyi-orosz szövetségterv heletkezése. Magyar-orosz történelmi kapcsolatoh. Budapest. 35-57. 1 
Wójcik Zbigniew. (1973). Czy Kozacy Zaporoscy byli na służbie Mazarina? Przedląd Historyczny. Zesz. 3. 1973. T. 64. S. 580-585.

Zmrcz B. (Zimorowic Józef Bartłomej). (1620). Żywot kozaków Lisowskich. Także i potyczki ich szczęśliwe. Kraków. 140 s.

Voitovych Leontii

PROBLEMS OF PARTICIPATION OF THE UKRAINIAN COSSACKS ARE IN OF THIRTY YEARS WAR

In research the debatable problems of participation of the ukrainian cossacks are taken apart in of Thirty Years war 1618-1648 and the stetejtypes related to them. These stereotypes remain the inheritance of Polish and Ukrainian patriotic historiography that tried to ascrite to «it» participating in general or and strager formation. Convolute attention to the teature of sets of forming of The Polish cossacks, socalled «lisovchycks». It is set that forming of «lisovchycks» were a lignt horse effective at implementation of reconnaissance and watch, tasks, raids on teritoty busy at an opponent and pursuet of recessive opponent. Forming of the Ukrainian cossacks were infantry, and infantry in the army of Polish-Lithuanian Commonwealth constantly it was not enough. Therefore to allow to hire other infantry except the Ukrainian cossacks Polish-Lithuanian Commonwealth did not simply could. During wars Poland hired the Hungarian, German or Czech infantry. Analysed battles under Humenne (1619), on the White mountain (1620), campaigns in Silesia, on Rhine, in Hessen and Luxemburg and the Baltic expedition. Reasonable hypothesis in relation to equality of colonel Taraski with a hetman by Fedorovych Taras (Trjasylo). In detail the problem of participation and role of cossacks is analysed in the receipt of Dunkirk (1646) and participating in these events of Bogdan Chmelnitsky, Ivan Sirko and Soltenko.

Keywords: of Thirty Years war, the ukrainian cossacks, the «lisovchycks», battle under Humenne, battle on the White mountain, battle at Ivoa, Dinkirk. 